\title{
文献の引用・被引用関係からみた中心地研究者間 のコミュニケーション・ネットワーク
}

原山道子

I はじめに

II 引用分析について

(1) 文献引用の意味

(2) 引用分析の諸概念

III 地理学における引用分析研究

(1) 研究の質・生産性・ランキング

(2) 承認・褒賞
(3) コミュニケーション・ネットワーク と研究テーマ・アイデアの伝播

IV 中心地研究の引用分析

(1) デー夕

（2）多次元尺度構成法 (MDS) による引 用分析

$\mathrm{V}$ むず
Iはじめに

一般に，学術論文には文献の引用 Citation の記述が不可欠である。本稿の目的は, 文献の 引用・被引用関係を明らかにする引用分析を用 いて, 計量書誌学的に, 地理学の一研究分野の 研究者間のコミュニケーション・ネットワーク を再現することにある。具体的には， Christaller 扝よび Löschを先駆とする中心地研 究の展開を, 関連論文の引用関係に基づいて数 量的に分析し, 研究者間のコミュニケーション ・ネットワークを求め, 引用分析の有効性を考 察しようとするものである。

本稿では, まず, 近年, 科学社会学 Sociology of Science や図書館・情報学 Library and
Information Science 等の分野で，研究動向を 把握するために行なわれるようになった引用分 析を概観する。次に，地理学における引用分析 研究を紹介する。そして, 最後に, 中心地研究 の分野を例として，引用分析を行なう。中心地 研究は, Christaller らの研究から半世紀がたち, 人文地理学の一分野として既に確立しており, 地理学史の中での位置づけが，(少なくとも初期 の研究に関しては) 明らかにされている。したが って，本稿で試みる分析や解釈が，既になされ ている中心地研究の研究史上の位置づけと比較 して，どの程度有効であるかをみることができ るのである。

\section{II 引用分析について}

1）文献引用の, 目的・効用についての図書館・情報学上の定義は, 坂本徹朗著「情報検索」（椎名六郎・岩猿敏生・河野 徳吉編『日本図書館学講座 9 !, 雄山閣), 1983，121一122頁を参照されたい。

2）本稿でいうコミュニケーションとは，ただ単に「知識・情報が（文献の引用・被引用によって）交換される」といった 広義の意味合いで使用されているものであり, 必ずしも研究者間の知己関係を通しての知識・情報の伝達を意味している ものではない。

3) Christaller, W., Die Zentralen Orte in Süddeutschland: Eine Ökonomishe-geographische Untersuchung über die Gesetzmassigkeit der Verbreitung und Entwicklung der Siedlungen mit städtischen Funktionen. Jena, Gustav Fischer Verlag, 1933, 330S. (クリスタラー著, 江沢譲爾訳「都市の立地と発展』, 大明堂, 1969, 396頁)

4) (1) Lösch, A., Die Räumliche Ordnung der Wirtschaft: Eine Untersuchung über Standort, Wirtschaftgebiete und Internationalen Handel. Fischer, Jena, 1940, 380S. (2)レッシュ著, 篠原泰三訳『レッシュ経済立地論』, 大明堂, 1968，622頁。ただし，この邦訳は，第 3 版1962の訳本である。）

5) James, P. E. and Martin, G. J., All Possible Worlds: A History of Geographical Ideas, 2nd ed. John Wiley \& Sons, 1981, 415p. 
(1)文献引用の意味＼cjkstart文献の引用は，展望論 文に限らず，あるテーマを研究し完成させるた めに，関連する先行研究の中での，その論文の 位置づけを明確にする意味あいを有している。 したがって，引用を文献間の関係を示す尺度に 利用することができるのである。 J. Cole and S. Coleによれば, 文献の被引用数は, 次のよ うに 4 つの意味をもつ変数とみなすことができ る。

1）研究の質の指標: 質の高い研究は, 同じ 分野の研究者にあまねく有益と考えられるもの であるから，数多く引用されることになる。

2）研究業績に対する承認の指標:「科学者 であるということは, 同じ分野の研究者が彼の 研究業績を参考文献に挙げるという形で, 科学 の社会制度の中で彼の研究を評価したときに初 めて確かなものとなる」。したがって，この第 2 の考え方は, 科学社会学でいう「隹賞」の) の概 念と深く関わっている。

3）アイデアなどの伝播の指標: 科学者のコ ミュニケーションが引用・被引用関係によって 明らかとなるという意味で，こうした関係の分 析は, コミュニケーション・ネットワークを知 る手がかりのひとつをあたえるものと理解する ことができる。

4）刊行物の利用の際の指標: 科学者として 認知されるためには, 最低条件のひとつとして, 公刊された著作・論文を利用した際, その出典
を明らかにする義務と必要がある。引用文献の 明記を亮って引用を行なった研究者は，他の研 究者の知的生産物を盗んだことになり，なんら かの制裁を受けることになる。

ところで，本稿の目的である，引用関係を視 覚化して学問・研究者間のネットワークを明ら かにしょうとする試み，すなわち，J. Cole and S. Cole の指摘した第 3 の意味での引用・ 被引用関係の研究は, 1960年代初頭からみられ, 多変量解析が普及した近年, 特に科学社会学, 図書館・情報学の分野で盛んに行なわれるよう になった。

科学社会学では, 1960年代中葉から, 若手の 研究者達によって, 計量的手法を用いて Kuhn のパラダイム概念を実証することを目的とする 研究が行なわれてきた。それらの実証研究は, 学問・研究者のコミュニケーション・ネットワ ークのみならず，生産性，褒賞体系等に関する 計量的研究であった。こうした実証研究は, Garfield によって考案され，1963年から発行さ れるようになった『科学引用索引 Scientific Citation Index』(以下 SCI と略す) が供給する デー夕を使用することによって飛躍的に増大し た。SCIは主に自然科学の分野を対象にした 索引であるが，後に，『社会科学引用索引 Social Sciences Citation Index』(以下 SSCI と略 す), 『人文科学引用索引 Arts and Humanities Citation Index』(以下 A \& HCI と略す) も出版

6) Cole, J. and Cole, S., Social Stratification in Science, Univ. of Chicago Press, 1973, pp. 21-36.

7) マートン, R.K.著, 成定薰訳『科学社会学の歩み一エピソードで緅る回想録』, サイエンス社, 1983，83-86頁。

8）前掲7)によれば，科学上の貢献に対しての「住賞」とは，第一義的には金銭ではなく，自分の研究が科学の前進にとっ て大きな価值をもつことを同業者から認知してもらうことであり, 被引用の他に, 各種の賞や, 栄誉的な役職, 地位, 知 名度などがその指標として用いられている。

9）この分野のレビュー論文としては, 緑川信之・松山浩一『図書館情報学に関する計量的研究一調査とレビュー一』, 図 書館情報大学研究報告 $3-2,1984,11$ - 33 頁がある。

10）科学における「生産性」とは，ひとりの研究者がある一定の期間内に公表した論文や著書の数であり，前掲6)による第 2 の指標である「研究業績に対する承認」と関連している概念である。

11）なお，褒賞体系論とは，R. K. Mertonの科学社会学理論の中枢をなす理論で，科学制度には隹賞体系が備わっており， 科学上の貢献に対して付与される襄賞 (前掲注8)参照) が科学の自立的な発展の基盤になるとされる。その実証研究は, 主として, 科学上の承認，すなわち専門的認知が，その科学者の所属する社会 (学会) において，どのようになされるか を分析するものである。

12）新堀通也『学問の社会学】, 東信堂, 1984, 66頁。

13) Garfield, E., 'Citation indexes for science', Science, 122, 1955, pp. 108-111. 
されるようになり，引用分析は，自然科学のみ ならず，社会科学の分野においても容易に行な えるようになった。

他方, 図書館・情報学の分野では, Hulme が1922年に用いた統計書誌学 Statistical bibliographyという語に代わり，Prichardが計量 書誌学 Bibliometrics という用語を1969年に提 唱した。以後, この計量書誌学という用語が図 書館・情報学の分野で一般に用いられている。 計量書誌学は, 広義には「図書やコミュニケー ション・メディアへの数学的および統計学的方 法の適用」であるが, 本稿では狭義の「書誌デ 一夕の計量的分析」と解釈し, いわゆる図書館 - 情報学的にいわれるところの内容分析 Content analysis までは含んでいない。

( 2 )引用分析の諸概念 ここで, 引用・被引 用の関係をみる場合の, 引用の扱い方について ふれておくことにする。それは，引用を，直接 的に扱う場合と間接的に扱う場合とに大別でき る。直接的な扱い方とは, 引用回数そのものを 単純にカウントして引用・被引用関係を扱うも のである。一方, 間接的な扱い方とは, なんら
かの測度を用いて引用・被引用関係を扱うもの で，基本的には，引用側を対象とするものと， 被引用側を対象とするものとに分けられる。こ のうち，引用側を対象として分析するための概 念としては，書誌結合 Bibliographic coupling や連鎖結合 Link connection があり, 被引用側 を対象として分析するための概念としては，共 引用 (または, 組引用) Co-citation がある。以 下, これらの諸概念について簡単に述べること にする。

Garfieldは， Asimovの著書にあるDNA 関 係の文献からみた研究者の関連図と, SCI で 引用関係を調べて作成した研究者のネットワー クとがほぼ一致することを示したが，これは， 直接的に引用（数）を扱った分析として有名で ある。

書誌結合は，Kessler が定義した概念で，共 通引用件数を測度とし, 引用側の結合度を测る 尺度である（第 1 - $\mathrm{a}$ 図参照）。論文 $\mathrm{A}$ と論文 $\mathrm{B}$ が，直接の結びつきはなくとも，共に論文 $\mathrm{C} を$ 引用しているとき, A と B は書誌結合があると いい,この場合の A と B の結合度は 1 である。

14） SCI は, フィラデルフィアの科学情報研究所 Institute for Scientific Information, Philadelphia が年 4 冊（第 4 冊目は, 最後の 3 カ月を含めその年の全蓄積版として) 発行している。他に, 5 年分の蓄積版もある。収録対象誌は, 2,600 誌に のぼり, 収録対象論文数は約 50 万件, 引用件数は約 650 万件である。SCI は, 1) 引用索引Citation Index, 2) 情報源索 引 Source Index, 3) 回転式キーワード索引 Permutern Subject Index の 3 種類の索引からなっている。引用索引には, 引用された論文や著書の著者名, 発表年, 雑誌・著書名, ページが著書名のアルファベット順に列挙され, それを引用し た者の氏名, 雑誌名, 巻号, ページが記載されている。情報源索引には, 収録雑誌の全論文の書誌事項が, 著者名のアル ファベット順に書かれている。回転式キーワード索引には, 引用索引の論文・著書のタイトルから抽出されたキーワード のアルファベット順の見出しの下に，その論文・著書の著者名が載っている。

15） SSCI, A \& HCI とも, SCI と同じく, 科学情報研究所が刊行しており，SSCI は，1972年，A＆ HCI は1977年から発 刊された。内容は, SCI とほぼ同じである。

16) . Hulme, E. W., Statistical Bibliography in Relation to the Growth of Modern Civilization. London, 1923. (筆者 未見）

17) Prichard, A., 'Statistical bibliography or bibliometrics?', Journal of Documentation, 25-4, 1969, pp. 348-349.

18）緑川信之・倉田敬子・真弓育子他『図書館・情報学のための調査研究法』(図書館・情報学シリーズ 5 ), 1986, 勁草書 房, 56頁, 76頁。

19）内容分析は, マス・コミュニケーションの分野から科学社会学や図書館・情報学にとりいれられた手法で, 情報を, 書 誌事項ではなく, 「文献の内容」に限定し, 計量的に扱㧍うとするものである。伝達メディアの特徴を調べたり, それら の伝わり方,「読みやすさ Readability」を測定したりする。計量書誌学的に内容分析を行なうのであれば, 単純に引用頻 度をカウントするのではなく, 引用の目的を吟味することになる。例えば, ただ単に儀礼的に引用しているのか, 自説を 述べるのに補助的に引用しているのか, 被引用者の説を肯定的に引用しているのか, あるいは否定的に引用しているのか 等を細かく検討することになる。

20) Garfield, E., 'Historiographs, librarianship, and the history of Science.', in Rawski, C. H. ed. Toward a Theory of Librarianship, Scarecrow, 1973, pp.380-402.

21) Asimov, I., The Genetic Code, New American Library, 1962. (筆者未見)

22) Kessler, M. M., 'Bibliographic coupling between scientific papers', American Documentation, 14, 1963, pp. 10-25. 

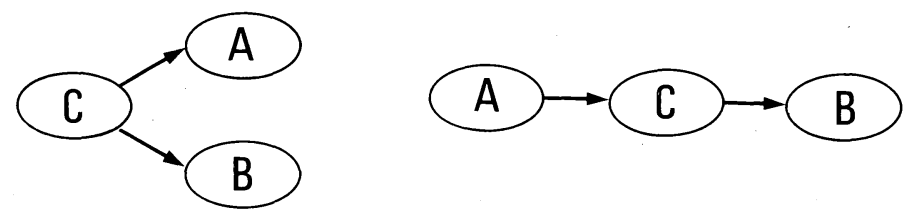

1-a: 書誌結合 Bibliographic coupling

$1-b$ : 連鎖結合 Link connection

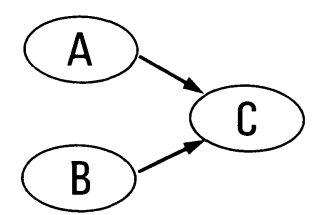

1 - c : 共引用 Co-citation

第 1 図引用関係の間接的な測定

Fig. 1 Indirect measurements of citation

さらに共に論文Dを引用している場合は，両者 の結合度は 2 となる。

連鎖結合とは, 論文 $\mathrm{A}$ を論文 Cが引用し, 論 文 C を論文 Bが引用したときに，論文 $\mathrm{B}$ と A 直接の引用関係がなくとも, 論文 $\mathrm{C}$ をして結 合しているとみなす考え方である（第 1 - b 図 参照）。引用する側を列に, 引用されている側 を行にとって, 引用数を行列にすると, 引用・ 被引用関係のわかる行列（以下「引用行列」とい う）ができる。連鎖結合をみる場合は，まず， 引用行列をつくる際, 出版年の古いものから順

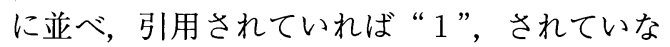
ければ “0”のバイナリー行列にする。このま までは直接の引用関係を示す引用行列にすぎな いが，この行列を $n$ 乗することによって，間 接的（連鎖的）な引用関係を示す $\mathrm{n}$ 連鎖結合行 列ができあがる（ちなみに，第 1 - b 図は，2 連 鎖結合の図である)。

共引用は，Small によって提案された概念で, 出版されたときには，互いに独立・無関係であ った 2 つ文献 $\mathrm{A}$ と B が，後に別の文献 Cに共 に引用されたとき，その 2 つの被引用文献 $\mathrm{A}$ と $\mathrm{B}$ の間に関係があるものとみなし，その頻度を カウントするものである。したがって，これは 被引用側の結合度を測る尺度である（第 $1-\mathrm{c}$ 図参照)。
書誌結合は，すでに発表されている文献であ る A と B の間に，共通する引用文献 Cがいくつ あるかを問題にするという意味で固定的である。 それに対し, 共引用の場合は，AとBを共に引 用する文献 Cがいくつあるかを問題にするとい う意味で，時間的に変化する（この先も引用され る）可能性があり，動的であるといえる。なお， 前述の連鎖結合も，行列が時系列でならんでい るため，時間変化に対応できる概念である。

上記諸概念に基づいて作成される引用行列に 対して適用される分析手法としては, 多变量解 析の中でも，似たもの同志をまとめ，類型化す る場合に用いられるクラスター分析, 相関関係 を規定する潜在構造を知るのに適している因子 分析，空間構造そのものの分析に適している多 次元尺度構成法 Multi-Dimensional Scaling (以下 MDS と略す) がよく用いられている。

これらの手法を用いて引用分析を行なう場合， 分析に先立って, 何らかの形で原データをグル ーピングするのが一般的である。例えば，宮本 ・中山が対象にした計測・制御関係の文献の総 数は 3,505 件, 引用文献の総数は 26,096 件であ るが, 5 回以上引用されているという条件で, まず，225の文献を選び，それぞれを引用して いる文献を個別に抽出して225のグループを作 った。さらに各グループの重心を計算して代表

23）この計算過程は省略するが，手続き的には，グラフ理論を用いて近接性を求める場合と同様である。

24) Small, H., 'Co-citation in the scientific literature: a new measure of the relationship between two documents', Journal of the American Society for Information Science, 24, 1973, pp. 265-269.

25）宮本定明・中山和彦「引用傾向の類似性に基づく文献クラスタリングの一手法」, Library and Information Science, No. 17,1979 , pp. 93-102. 
となる文献を選び出し，それらを2250初期ク ラスターとして分析を行なっている。こうした 操作を施すのは，ひとつには，SCI などの大 量のデー夕を分析する際，計算機の容量に制約 があるからであり，また，扱いやすい量（ある いは形）にすることによって結果の解釈が容易 にもなるからである。

\section{III 地理学における引用分析研究}

近年, 地理学の分野でも, 欧米を中心として, 引用分析研究が増加しつつある (第 1 表参照)。 それらは, 科学社会学, あるいは図書館・情報 学において用いられる手法や概念を地理学に導
入したものである。そこでは，1）研究の質・ 生産性・ランキング，2）承認・褒賞，3）コミ ュニケーション・ネットワークと研究テーマ・ アイデアの伝播などが, 引用分析を用いて研究 されている。これらは, 前述の J. Cole and S. Cole の分類の第 1 から第 3 のものにあたる。 以下では，こうした地理学における引用分析研 究について概観することにしたい。

(1)研究の質・生産性・ランキング 科学社 会学的に, 地理学者 (英国地理協会 Institute of British Geographers のメンバーを対象) の質・生 産性を調べ,さらに地理学の引用構造を明らか にしたのは, Stoddart が最初であろう。彼は,

第 1 表 地理学における引用研究

Table. 1 Summary of studies on citation analysis in geography

\begin{tabular}{|c|c|c|c|}
\hline 者 & 発表年 & 料 & 内 容* \\
\hline Bunge, W. & 1961 & 3 journals & $\mathrm{C}$ \\
\hline Stoddart, D. & 1967 & Number of periodicals, books, etc. & $\mathrm{P}, \mathrm{Q}$ \\
\hline Clayton, K. M. & 1970 & SCI & $\mathrm{C}$ \\
\hline Baker, A. H. R. & 1973 & 1 journal & Q \\
\hline Duncan, S. S. & 1974 & SCI, 7 journals & $\operatorname{Re}$ \\
\hline Haigh, M. J. & 1975 & 'Universitylevel' textbooks & $\mathrm{C}$ \\
\hline Whitehand, J. W. R. \& Edmondson, P. M. & 1977 & 17 journals & $\mathrm{C}$ \\
\hline Hay, A. M. \& Maddock, S. & 1981 & SSCI & $\mathrm{P}$ \\
\hline Gade, D. W. & 1983 & 3 journals & $\mathrm{O}$ \\
\hline Wrigley, N. & 1983 & SSCI, SCI, A \& HCI & $\mathrm{C}$ \\
\hline Gatrell, A. C. & $1984 a$ & 13 journals & $\mathrm{C}$ \\
\hline Gatrell, A. C. & $1984 \mathrm{~b}$ & 14 papers & $\mathrm{C}$ \\
\hline Gatrell, A. C. \& Smith, A. & 1984 & 22 journals & $\mathrm{C}$ \\
\hline Whitehand, J. W. R. & 1984 & SSCI & $\mathrm{Ra}$ \\
\hline Gould, P. & 1985 & 12 journals & $\mathrm{C}, \mathrm{Ra}$ \\
\hline Hay, A. M. & 1985 & SSCI & $\mathrm{P}, \mathrm{O}$ \\
\hline Peet, R. & 1985 & Bibliography & $\mathrm{Ra}$ \\
\hline Turner II, B. L. \& Meyer, W. B. & 1985 & SSCI, SCI & $\mathrm{Ra}, \mathrm{Q}$ \\
\hline Whitehand, J. W. R. & 1985 & $\mathrm{SSCI}$ & $\operatorname{Re}$ \\
\hline Wrigley, N. & 1985 & SSCI, SCI, A \& HCI & $\mathrm{Ra}$ \\
\hline Wrigley, N. \& Mathews, S. & 1986 & SSCI, SCI, A \& HCI & $\mathrm{O}$ \\
\hline Bentham, G. & 1987 & SCI, SSCI & $\mathrm{Ra}$ \\
\hline Trimble, S. W. & 1987 & SCI, SSCI & $\mathrm{O}$ \\
\hline
\end{tabular}

26）以上述べてきた引用分析のより詳しい説明は，次のものを参照されたい。Garfield, E., Malin, M. V. and Small, H., 'Citation data as science indicators', in Elkana, Y., Lederberg, J. et al. eds., Toward a Metric of Science, John Wiley, 1978, pp. 179-207.

27) Stoddart, D. R., 'Growth and structure of geography', IBG Trans., N. 41, 1967, pp. 1-18. 
引用の半減期 Half-life を指標にして, 地理学 の専門分野間の違いを具体的に検証し，引用分 析の有用性を明らかにしている。なお彼は, 論 文の最後の部分で, Geographical Abstracts 誌 が, 地理学の発展や, 構造そのものを解明する ためのデータ・ソースとして使われる可能性を 予測している。Bakerは, Stoddard と同様の 分析を Progress in Historical Geography 誌 を対象にして行ない, 歴史地理学における引用 構造を明らかにした。それによると，引用の半 減期が地理学全体の平均 7.5 年に対して 4 年と 短いこと，また，プライス指数 Price's-Index （ある雑誌が引用している全ての文献の中で, 最近 5 年以内に刊行された文献が引用される割合）が，地 理関係の154雑誌では平均で32\%,リサーチ・ フロントでは $42 \%$ 以上であるのに, Progress in Historical Geography 誌の場合は, プライ ス指数が平均で $38 \%$ ，方法論を扱った文献の場 合は $54 \%$ と，高率になることなどを指摘してい る。

また, Hay and Maddock は, 1974年から 1984年にかけてのイギリスの人文地理学の分野 を対象にして，学位論文が他の研究者に及ぼし た影響の大きさについて述べている。さらに Hayは，SSCI を用い，イギリスの人文地理関 係の209論文を対象に生産性の分析を行なうこ
とによって，量の面からだけでなく， 影響力の 面でも学位論文の重要性を再確認している。こ の論文の中で, 彼は, East Midland Geographersや Cambria といったサーキュレー ションのよくないイギリス国内の雑誌よりも， Environment \& Planning A (以下, E \& PA と 略す) や Regional Studies といった国際的・学 際的な雑誌に載っている論文の方が, はるかに 高い影響力があることも指摘している。

Bentham は, 出版物 · 引用数 · 研究補助金 の受領額のそれぞれを指標にして，イギリスの 大学の地理学教室を評価し, 大学研究費助成委 員会 University Grants Committee (UGC) に よってなされた評価と比較している。彼は，引 用数からみた評価と研究補助金の受領額からみ た評価との相関が低く，しばしば矛盾さえ生じ ていることを指摘し，評価が指標によって左右 されてしまう現状について述べている。

他方, Turner II and Mayerは, Morrill や 全米学術会議 National Research Council が行 なったアメリカの大学のランキングを紹介し， SCI ならびにSSCI を用いて， 6 通りの視点で アメリカの大学の質の面からのランクづけを示 している。またTrimble は，その Turner II and Mayer 論文の方法と結果については, SCI と SSCI で重複しているデータの処理, 同

28）引用文献数をそれらの刊行年順に累積してみると，その数は時間と共に指数関数的に減少する。その累積の中央值をと るまでの時間を, 半減期と定義する (Burton, R.E. and Kebler, R.W., 'The 'half-life' of some scientific and technical literatures', American Documentation, 11-1, 1960, pp. 18-22.)。

29) Baker, A. R. H., 'A cliometric note on the citation structure of historical geography', Prof. Geogr., 25-4, 1973, pp. 347-349.

30) Hay, A.M. and Maddock, S., 'The contribution of postgraduate thesis research to the published literature of human geography in the United Kingdom', Social Science Information Studies, 1, 1981, pp. 165-172.

31) Hay, A. M., 'Some differences in citation between articles based on thesis work and those written by established researchers: human geography in the UK 1974-84', Social Science Information Studies, 5, 1986, pp. 81-85.

32) Bentham, G., 'An evaluation of the UGC's ratings of the research of British university geography departments', Area, 19-2, 1987, pp. 147-154.

33) Turner II, B. L. and Meyer, W. B., 'The use of citation indices in comparing geography programs: an exploratory study', Prof. Geogr., 37-3, 1985, pp. 271-278.

34) Morrill, R. L., 'Productivity of American Ph. D.-Granting Departaments of Geography', Prof. Geogr., 32-1, 1980, pp. 85-89.

35) Jones, L. V., Gardner, L. and Porter, E. C. eds., An Assessment of Research-Doctorate Programs in the United States: Social and Behavioral Sciences. Washington, National Academy Press, 1982. (筆者未見) 
姓同名の研究者の扱い等, 4 点からなる欠陥の 指摘を行なっている。

Peet は, Lee and Evansが, アメリカの地 理学者を対象にしたアンケート調査をもとにし て得た雑誌のランキング結果を，引用分析を用 いて批判している。また Whitehand は, 1978 年から1982年の科学情報研究所のデー多から, 影響力の高い地理学の一般誌として, Annals of the Association of American Geographers（以下 AAAG と略す), Transactions of the Institute of British Geographers (以下 Trans. IBG と略す), Geographical Analysis, Geographical Review（以下 GR と略す）の 4 誌 をあげ，同じく影響力の高い専門誌として， Journal of Biogeography, Economic Geography (以下 EG と略す), Regional Studies, E \& PA などをあげている。

( 2 ) 承認・褒賞 Whitehand は引用頻度を 承認の指標として用いて，1970年代初頭の人文 地理の発展を検証した。彼は, SSCIを用いて 引用分析を行なった結果, 都市・経済地理学に おいては, 北アメリカの大学の研究 (者) が多 く引用されていることを示している。

また, Duncanは, Hägerstrand の拡散研究 を例にして，科学上の新しいアイデアが承認さ れるまでの過程について述べている。それによ ると, 他の科学と同様, 地理学においても, ア イデアが受容されるまでには拒否反応があるが,
それは言語の障壁（彼の著作が英語で著されてい なかったこと）ばかりでなく，Mertonが定義し あマタイ効果 Matthew effect（集賞機構, 資源 配分, 社会的な選抜機構など, 科学研究のための有 利な条件は，一流機関に属する研究者に偏って配分 される゙）も認められるとしている。なお，引用 文献の国別の平均数を出し，それらを比較する ことによって，イギリス，アメリカ，ポーラン ドの地理, 地形 (地質も含む) 関係の論文の場 合の引用傾向を述べている Clayton によると，

1）いずれも自国の文献を引用する割合が多い が，アメリカに拈いてそれが最も顕著であるこ と，2）外国の文献を引用する場合は，古典的 な文献が多く，最近のものは無視する傾向にあ ること，3）したがって英語以外の言語で書か れた論文に，英語のアブストラクトがついたも のより, Geographical Abstracts 誌のような二 次資料に書誌情報として載ったものの方が，よ り広範囲に受容されやすいこと, などが明らか にされている。また，引用分析研究とは言えな いが, Gadeは, アメリカの地理学界において 外国語が無視されていることの例証のひとつと して, AAAG, GR, EG 3 誌に載録されてい る論文の引用文献の中で, 英語の文献の占める 割合が高率（それぞれ88\%，87\%，94\%）である ことを指摘している。

( 3 )コミュニケーション・ネットワークと研 究テーマ・アイデアの伝播 引用されるという

36) Trimble, S. W., "The use of citation indices in comparing geography programs: an exploratory study": Some comments', Prof. Geogr., 39-2, 1987, pp. 202-203.

37) Peet, R., 'Evaluating the discipline's journals: a critique of Lee and Evans', Prof. Geogr., 37-1, 1985, pp. 59-62. なお，その批判の対象となった論文は次のものである。Lee, D. and Evans, A., 'American geographers' rankings of American geography journals', Prof. Geogr., 36-3, 1984, pp. 292-300.

38) Whitehand, J. W. R., 'The impact of geographical journals: a look at the ISI data', Area, 16-2, 1984, pp. 185-187.

39) Whitehand, J. W. R., 'Contributors to the recent development and influence of human geography: what citation analysis suggests', IBG Trans. N.S., 10, 1985, pp. 222-234.

40) Duncan, S. S., 'The isolation of scientific discovery: in difference and resistance to a new idea', Science Studies, 4, 1974, pp. 109-134.

41) Merton, R. K., 'The Matthew effect in science', Science, 159, 1968, pp. 56-63.

42) Clayton, K. M., 'Publication and communication in geography', Geogr. Polonica, 18, 1970, pp. 13-20.

43) Gade, D. W., 'Foreign languages and American geography', Prof. Geogr., 35-3, 1983, pp. 261-266. 
形で科学者として認知されること, すなわち科 学社会学的な意味で襄賞を得ることは, 同時に, その研究テーマやアイデアが伝播し, 研究者間 にコミュニケーション・ネットワークが作られ ることをも意味する。

地理学者のコミュニケーション・ネットワー クを最初に問題としたのは Bungeである。彼 は, AAAG, GR，EGの 3 誌の1958年から 1960年にかけての掲載論文を調べ，文献が引用 されている地理学者数が796人であることを確 認した。次いで，その中から 4 回以上引用され ている86人を抽出し，引用行列を作成した。そ して, 引用・被引用数に基づいてグルーピング した86人のコミュニケーション・ネットワーク を示した。このコミュニケーション・ネットワ ークには, Garrison, Berry, Marble 等からな るワシントン学派のグループと, Hartshorne や Humboldt, Jones, Trewartha を中心とした 伝統的地理学者のグループを両極にして，その 間に James を中心としたグループなど，いく つかのクラスターがみられた。

雑誌間のコミュニケーション・ネットワーク を扱った Wrigley は, SCI, SSCI, A \& HCI から, 引用数の多い地理学関係の雑誌をあげ,

E \& PA 誌の位置づけを行なっている。Gould は，雑誌間の引用頻度の差を“流れ”とみなす ことによってできる影響力の地図 “Wind of influence” map を，1975年と1980年について 作成し, EG が中心で, GR, Trans. IBG, 次い でAAAG が影響力をもっていた構造が，1980
年には, AAAG 中心に変わり，Trans. IBG の影響力が低下したことを指摘している。彼は また同書のなかで, Professional Geographer （以下, Prof. Geogr. と略す）に採録されている地 理学者のネットワークを，引用関係を多面体の つながりで表わすことによって表現し，アング ロサクソンの研究者のネットワークの緊密さを 明らかにしている。

より明確に雑誌間のコミュニケーション・ネ ットワークを解明しようとしたものとしては, 1970 1972年と1980〜1982年の 2 時期について, 掲載論文から 22 の地理学関係雑誌相互の引用関 係を，MDSによって分析した Gatrell and Smith の研究がある。そこでは, AAAG と $\mathrm{EG}$ が “引用空間” の中心をなしていることが 示されるとともに, $\mathrm{E} \& \mathrm{PA}$ 誌のこの面での近 年の台頭も明らかにされている。

さらに, Gatrell は, SCI を用いて, 13の地 理学関係の雑誌の1960年から1978年にかけての 掲載論文のうち，空間的拡散モデル関係の64論 文を選び出し，他に14論文を追加した78論文に ついて共引用関係を調べ，MDS と Q-Analysis を適用し，引用分析を行なった。これは，地理 学の特定研究分野内での研究動向の進展を, 引 用分析によってとらえようとした最初の試みで もある。同年，彼は，前述の論文を発展させた 形で, 同じ空間的拡散モデル関係の14論文に Q-Analysis を適用し，その中で用いられてい る用語の内容分析を行なうことによって，用語 の階層を導きだし, 研究動向の把握を試みてい

44) (1) Bunge, W., 'The structure of contemporary American geographic research', Prof. Geogr. 13-3, 1961, pp. 19-23.なお，そこに揭載されている行列を加工してMDSにかけ，地理学者の親近性空間を復元したものとしては，次 のものがある。(2)杉浦芳夫『パソコンによる数理地理学演習, §7 : 計量革命と統計学』, 古今書院, 1986, pp. 187-216.

45) Wrigley, N., 'The half-life of an E \& P', Environ. Plann. A, 15, 1983, pp.571-578.

46) Gould, P., The Geographer at Work, Routledge \& Kegan Paul, 1985, pp. 201-202, 335.

47) Gatrell, A. C. and Smith, A., 'Networks of relations among a set of geographical journals', Prof. Geogr., 36-3, 1984, pp. 300-307.

48) Gatrell, A. C., 'The geometry of a research specialty: spatial diffusion modelling', Ann. Assoc. Amer. Geogr., 74-3, 1984, pp. 437-453.

49）数学者の R.H. Atkin が考案した代数的位相幾何学の概念を用いた分析法。 
50)

る。

他方，コミュニケーション・ネットワークを 介してのアイデアの伝播に言及したものとして は, 次の 2 つがある。 Whitehand and Edmondson は, 北アメリカと西ヨーロッパで 発行されている主要な地理学関係の17雑誌を対 象にして，1954～1974年を 5 年ごとに分け，著 者の国別に引用分析を行ない, 戦後のヨーロッ パ地理学 (者)におけるアメリカ地理学 (者) の影響について論じている。また, Haighは, イギリスの地形学者の引用分析から，ヨーロッ パや他の国々の地形学 (者)に比して, アメリ 力の地形学 (者) が, イギリスの地形学 (者) に強い影響を与えていると述べている。

\section{IV 中心地研究の引用分析}

(1)データ 中心地研究が飛躍的に展開した 最初の時期は，1930年代から1960年代にかけて である。本稿はこの時期を扱うが，対象にする 文献の大部分は, SCI や SSCI, A \& HCI 等が 未だ刊行されていない頃のものである。そこで， 資料としては, Berry and Predの “Central Place Studies”を用いた。同書は, 中心地研究 のビブリオグラフィーであり，501人の672の文 献が, 内容の主題別に16項目に分けられて採録 されている。収録誌は, そこでの分類によると,
5 分野 (Geography, Regional Science, Sociology, Economics and Business, Land Economics and Planning）の64雑誌である。その中から, 今回 の分析には，採録論文数の多い「地理学」関係 の 8 誌 (AAAG, EG, GR, Geographical Journal, Geography, Lund Studies in Geography Ser. B (Human Geography) , Scottish Geographical Magazine, Trans. IBG) と, 「地域科学」関係の 1 誌 (Papers and Proceedings of the Regional Science Association）を選んだ。ただし，単行本 は対象にしなかった。その結果，対象論文数は 127，著者数は83名となった。対象論文のうち 刊行年の一番古いものは1928年，最新の文献は 1962年であるが，およそ $2 / 3$ の文献が1955年以 後に刊行されたものであった。

この選んだ83名の127論文の全てについて, 引用・被引用関係を調べ，各々の引用関係を力 ウントした。その際，自己引用はカウントせず， また，同一論文中における同一文献の被引用の 回数は，実際の回数に関わらず全て “ 1 ”とし た。また，引用・被引用論文とも，著者が複数 の場合はファースト・オーサーのみをカウント した。次に，1）文献が引用されていなかった 論文，とともに，2）文献は引用されているが, その被引用者が “Central Place Studies”の “Index of Authors”に載っていない者のみか

50) Gatrell, A. C., 'Describing the structure of a research literature: spatial diffusion modelling in geography', Environ. Plann. B, 11, 1984, pp. 29-45.

51) Whitehand, J. W. R. and Edmondson, P. M., 'Europe and America: the reorientation in geographical communication in the post-war period', Prof. Geogr., 29-3, 1977, pp. 278-282.

52) Haigh, M. J., 'National preferences in citation selection: British geographical geomorphology, 1970-1973', Area, 7, 1975, pp. 183-188.

53）なお, 以上の 3 つのカテゴリーに入らないものとしては, 地理学の主要 4 雑誌 (Area, Trans. IBG, AAAG, Prof. Geogr.）と単行本を対象にして, 引用頻度の高い論文や, 引用のレベルについて分析したもの（Wrigley, N. and Matthews, S., 'Citation classics and citation levels in geography', Area, 18-3, 1986, pp. 185-194. なお, Area の19巻 2 号 （1987）にこの Wrigley and Matthews 論文に関する短評が載っている（pp. 168-171）），都市・地域調査の分野で引用 されることの多い文献を SSCI, SCI, A \& HCI から求めたもの (Wrigley, N., 'Guest editorial. Citation classics in urban and regional research', Environ. Plann. A, 17, 1985, pp. 147-152), また Current Geographical Publications 誌に載っている地理学関係の雑誌のうち, 引用頻度の高い雑誌をリストアップしたもの (Gerould, A.C. and Warman, H. J., 'Most cited periodicals in geography', Prof. Geogr., 6-2, 1954, pp.6-12.) などがある。

54）森川は，1950年代の後半をひとつの区切りとしている（森川洋『中心地研究』，大明堂，1974，110頁）。

55) Berry, B. J. L. and Pred, A., Central Place Studies: A Bibliography of Theory and Applications. Bibliography Series, No. 1, Regional Science Institute, 1965, pp. 153，50. ただし本稿では, 後半の50頁の “Supplement through 1964 to Central Place Studies” (341編採録)は, 対象にしていない。 
らなっている論文を選び出した。これらは，そ れぞれ，1）引用分析を行なっても他の研究者 との関連がみられないこと，2）中心地理論と は関連が薄い文献であると思われること等から， 本稿の目的とはそぐわないと考えた。そこで, これらに該当する著者計 9 名を除き, さらに引 用数と被引用数の合計が 2 未満の者も除き, 最 終的に行方向に被引用者, 列方向に引用者をと った，57×57の引用行列を作成した（表省略）。

それによると, 最も被引用数が多いのは Christaller（36回）であり, Dickinson（34回） がそれに続き，F. H. W. Green (28回), Smailes（28回), William-Olsson(27回), Ullman (24回), Lösch (23回) の順となっている。 一方, 引用数が多い研究者としては, Godlund (63回), B. J. L. Berry（36回), Brush (35回), Carol (35回), Kant (24回), Philbrick (24回), F. H. W. Green（23回）らをあげることができ る。引用・被引用ともに多かったものは, Godlund, B. J. L. Berry, Brush, F. H. W. Green,である。de Solla Priceは, 引用行列に ついて, レビュー論文の場合は行方向に数值が 多く並び (引用文献が多い), 古典的な論文の場 合は列方向に数值が多く並ぶ（被引用回数が多 い）ことを指摘しているが，この場合もそれが あてはまる。すなわち, 被引用数が多い Christaller, Dickinson な゙゙古典的研究の推進 者は列方向に, Godlund, B. J.L. Berry, Brush らの比較的文献レヴューに多くの頁数をさいて いる研究者は行方向に, 多く数值が並んでいる。 そこで，この引用・被引用関係を示す数值を， 中心地研究者間の親近性を測る測度とみなし, MDS をこの行列に適用することによって, 彼
らのコミュニケーション・ネットワークを解明 してみることにしたい。

(2)多次元尺度構成法（MDS）による引用 分析 MDS は, データとして与えられる項目 間の “距離 (非類似性)”に注目して，データの 空間構造を復元しようとするものである。ここ では引用頻度の逆数を距離とみなし, 対象とし た地理学者の親近性を空間的にとらえようとし た。すなわち, 結果として, 引用・被引用数が 多い研究者は座標の中心に布置され, 親近性の 高い研究者が互いに近くに集まり，クラスター を形成することが予め想定される。

通常の MDSへの入力データである距離行列 は対称であるが，引用行列の場合は非対称であ る。そこで, この引用行列を, 対角要素を境に し, 行列要素の右上半分と左下半分を合計する ことによって, 対角要素を除いた三角行列に直 し，ノンメトリックな MDS にかけ，2次元解 を求めた。

収束解を得るための逐次計算回数は 100 回と し, 2 次元から 6 次元までの解を求めた。そし て，2次元解を除き，いずれの場合も順次次元 をおとしながら，最終的にそれぞれの解の 2 次 元解を求めた。結果的には，4 次元解を初期座 標とする 2 次元解が最も解釈しやすかった。こ れを, 横軸に 1 次元, 縦軸に 2 次元をとってプ ロットしたものが，第 2 図に示す引用空間であ

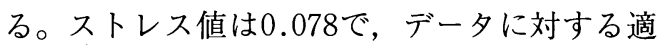
合度は良好である。なお, 以下の解釈を行なう に当たり，研究者の所属については“Orbis Geographicus”, 専門については “All Possible Worlds”を参照した。

復元された引用空間によると，被引用数の多

56) De Solla Price, D. J., 'Networks of scientific papers: the pattern of bibliographic references indicates the nature of the scientific research front.', Science, 149 (3683), 1965, pp. 510-515.

57）クラスカル，J.B., ウィッシュ，M. 著, 高根芳雄訳『多次元尺度法』(人間科学の統計学 1), 朝倉書店, 1980，110頁。

58）使用したのは同書の1960年版 (Meynen, E., Orbis Geographicus. Franz Steiner Verlag GMBH, Wiesbaden, 650p.) と, 1964/66年版 (Meynen, E., Orbis Geographicus Pt. II Geographers by countries. Franz Steiner Verlag GMBH, Wiesbaden, 511p.) である。 


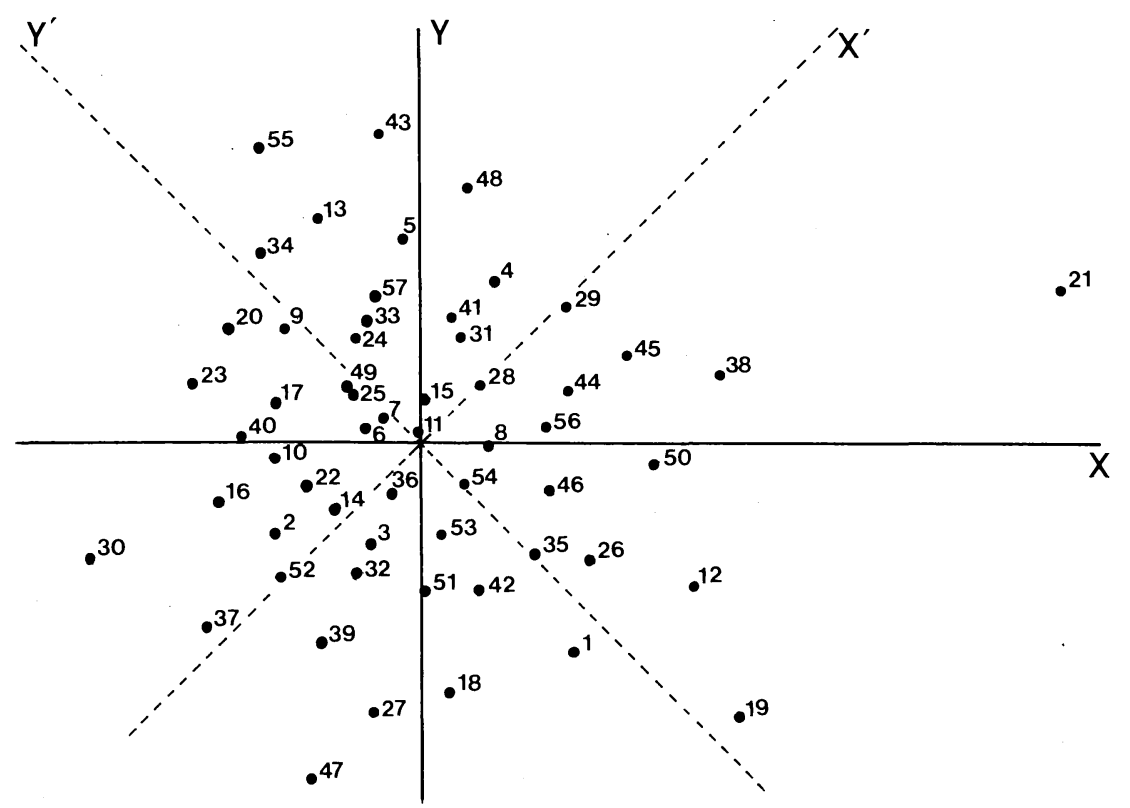
1. Applebaum, W.
4. Berry, W. J.
7. Brush, J. E.
10. Carter, $\mathrm{H}$.
13. Copland, B. D.
16. Duncan, O.D.
19. Epstein, B. J.
22. Garrison, W. L.
25. Green, F. H. W.
28. Harris, C. D.
31. Hywel Davies, D.
34. Leeming, F. A.
37. Marble, D.F.
40. Morrill, R. L.
43. Parkins, A. E.
46. Proudfoot, M. J.
49. Smailes, A.E.
52. Thomas, E. N.
55. Van Cleef, E.

2. Barnes, J. A.
5. Boustedt, O.
8. Carol, $\mathrm{H}$.
11. Christaller, W.
14. Dacey, M. F.
17. Dunn, E. S.
20. Fleming, J. B.
23. Gilbert, E. W.
26. Green, H. L.
29. Hartman, G. W.
32. Isard, W.
35. Lindstahl, S.
38. Mikesell, M. W.
41. Murphy, R.E.
44. Philbrick, A. K.
47. Roberts, J. M.
50. Spelt, J.
53. Trewartha, G. T.
56. Vance, J.E., Jr.
3. Berry, B. J. L.
6. Bracey, H.E.
9. Carruthers, W. I.
12. Cohen, S. B.
15. Dickinson, R.E.
18. Eiselen, E.
21. Fogg, W.
24. Godlund, S.
27. Greenhut, M. L.
30. Huff, D. L.
33. Kant, E.
36. Lösch, A.
39. Miller, H. V.
42. Nystuen, J. D.
45. Platt, R. S.
48. Scott, P.
51. Stewart, C. T.
54. Ullman, E. L.

第 2 図 MDS によって復元された 57 人の地理学者の引用空間

Fig. 2 Reference space of 57 geographers recovered by MDS

いChristaller と Lösch が図の原点近くに位置

していることがまず注目される。この引用空間 の特徵を把握するために，まず研究者達を国別 に分類してみた（第 3 図）。その結果, 全体の点 の布置は, ほぼ各象限別に特徵を有しているこ とがわかった。すなわち，まず第 2 象限にはヨ 一ロッパの研究者が集中し, 第 1 , 第 3 , 第 4 象限には北アメリカの研究者が位置しているこ とがわかる。ヨーロッパの研究者の集まってい
る第 2 象限に扔いては, Kant, Godlund, William-Olsson といったスウェーデンの地理学者 がひとつのサブ・クラスターを形成している。 そして，その周囲に位置する Copland, Leeming, Fleming, Caruthers, Gilbert, Smailes, F. H. W. Green, Bracey, 第 2 象限よりの第 3 象 限に位置する Carter, 第 2 象限よりの第 1 象限 に位置するDickinson らイギリスの研究者たち がもうひとつのサブ・クラスターを形成してい 


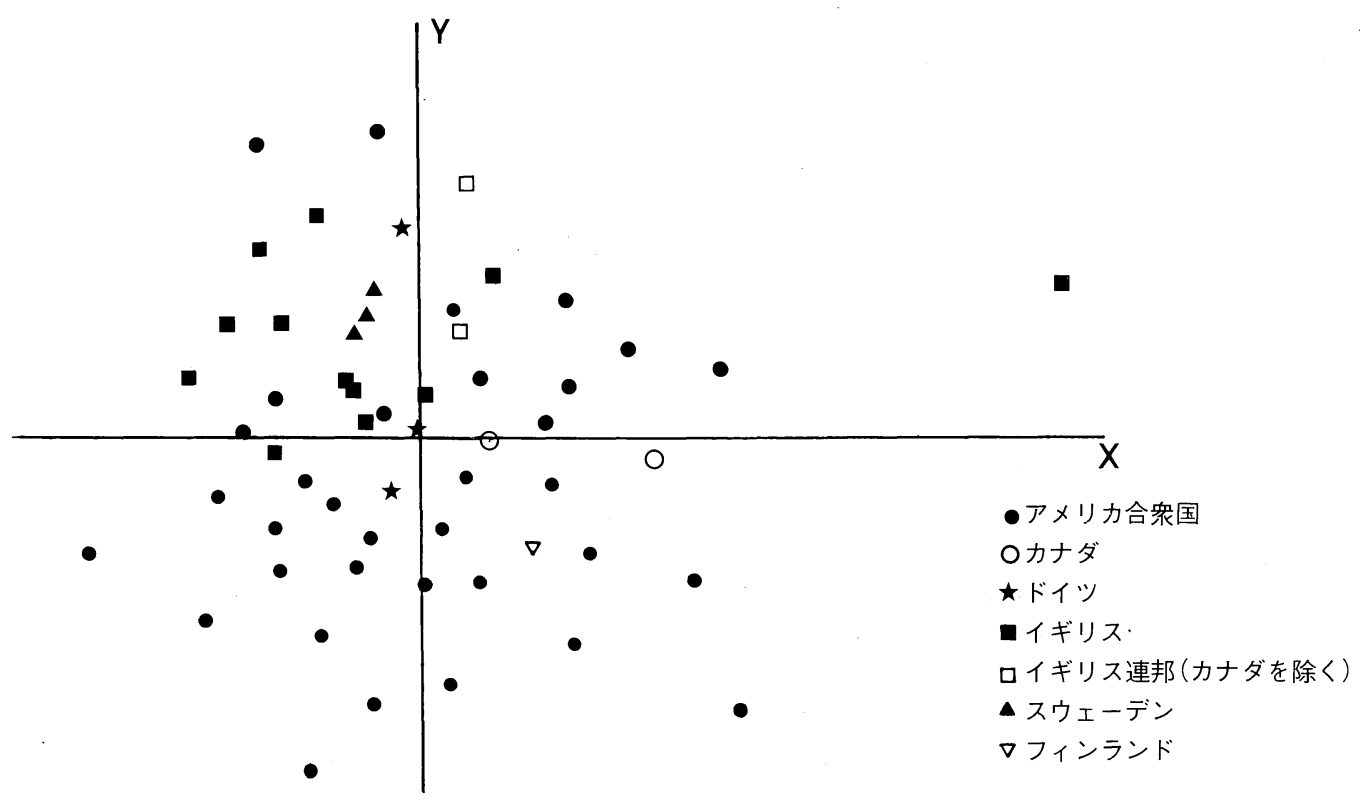

第 3 図 国別にみた地理学者の引用空間

Fig. 3 Reference space in terms of nationalities of 57 geographers

る。イギリスの研究者のクラスターの中でも， カタログ法を用いて研究を行なった Smilesや, バス路線網に着目して中心地勢力圈の画定に関 する一連の研究を行なったF.H.W. Green, ア ンケート調査から勢力圈を析出したBracey ら は, アメリカの研究者達により近い位置にある。 これは, 彼らの研究がアメリカの中心地研究 （者）により強い影響を与えたことの証左であ ろう。また, Christaller と研究方向が合致して いたとされる Dickinson〔注 54)95頁〕は, Chiristaller と親近性が高く, より原点近くにプ ロットされている。原データのカウントの際に は, この両者の互いの引用数は 0 であったが, それにもかかわらず位置が近いのは，被引用の パターンが似ており，他の研究者に同時に引用 されることが多かったためであると思われる。
なお，Dickinsonから影響を受け，アメリカに おいて地理学者による初めての本格的な中心地 の実証研究をしたとされる〔注54)96頁〕Brush が，第 2 象限の原点近くにおいて Dickinson や Christaller の近くに位置すると共に, 引用・被 引用関係の強かったイギリスの地理学者 Braceyにより近く位置している。

また, スウェーデン・フィンランドの北欧地 理学（者）の，アメリカへの紹介者であった Van Cleef も，周辺部ではあるが第 2 象限にお いて, ヨーロッパの地理学者の近くに位置して いる。逆にLösch が第 3 象限に位置している のは, 彼自身が, 戦前ハーバード大に滞在し, 自らの理論を裏づけるためのデータをアメリカ に求めたこと〔注4) (2) II, XIV 頁]からもわかるよ うに，アメリカの方に親近性が高く，ヨーロッ

59）例えば, Brush, J.E., 'Bus service hinterlands in Great Britain.' Geogr. Rev., 46, 1956, p. 269.

60) Brown, S. E., 'Eugene Van Cleef 1887-1973' in Freeman, T. W. ed., Geographers Bibliographical Studies Volume 9, Mansell, 1985, pp. 137-143. 
パよりも北アメリカの地理学者の間で引用され ることが多かったためと思われる。

次に，主として第 $1 ， 3 ４$ 象限に位置して いる北アメリカの研究者に関しては，学派別, あるいは専門別に検討することによって，その クラスターの内容を理解することができる（第 4 図参照)。まず，ワシントン学派といわれてい る, Dacey, Garrison, B. J. L. Berry, Marble, Morrill, Nystuen らを中心としたクラスターが 第 3 象限を中心にしてみられる。そして，それ に接して, 中心地理論を最初にアメリカに紹介 した研究者とされている Ullmanが，座標軸の
中心近く（第 4 象限）に位置している。彼は, Harvard 大の修士課程に在籍した際に Lösch と接触し，直接影響を受けており，偶然にもこ の引用空間上で Lösch の近くに位置している。 ちなみに，前述の紹介論文の草稿を準備しはじ めていた Ullman へ, Christaller の著作の存在 を示唆したのは Löschであったとされている。 また，地域科学を創始し，ワシントン学派に大 きな影響を与えた Isard は，ワシントン学派に 近いところに位置している。さらに，Isardの もとで学び, 後に農業立地に関する著作を著し た Dunn, 経済学者の Greenhut, 計量的手法を

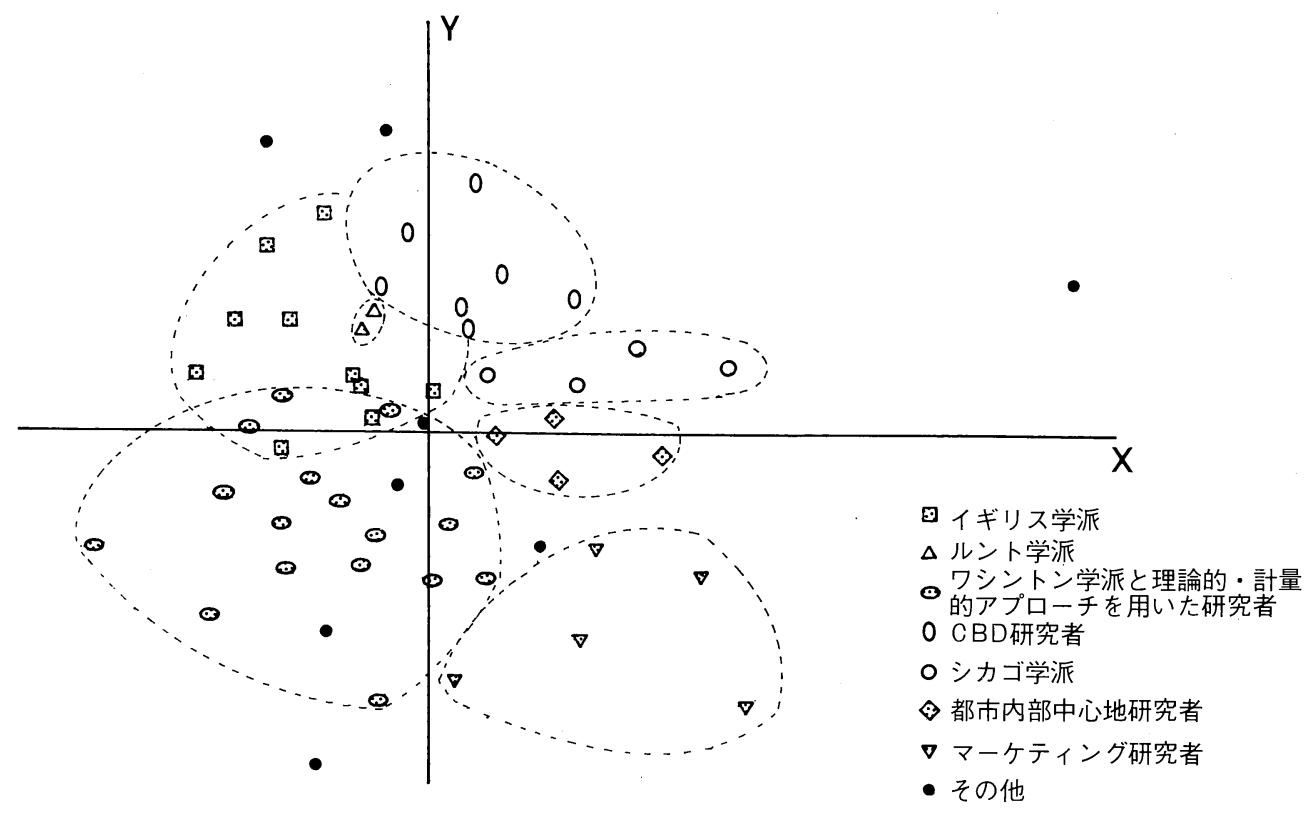

第 4 図 主な学派・専門別にみた地理学者の引用空間

Fig. 4 Reference space in terms of main schools or specialities of 57 geographers

61）イギリスの中心地研究者の F. H.W. Green は，その論文の中で，Löschの理想的経済景観 “ideal” economic landscape が実際のそれと非常にかけ離れていると述べている (Green, F. H. W., 'Community of interest areas : notes on the hierarchy of central places and their hinterlands', Econ. Geogr., 34, 1958, p. 211.)。本稿が対象にした文献の著者 で，Lösch を引用したヨーロッパの中心地研究者は，この F. H. W. Green と Godlund だけである。

62) Boyce, R. R., 'Edward Louis Ullman 1912-1976', in Freeman, T. W. ed., Geographers Bibliographical Studies Volume 9, Mansell, 1985, p. 130. 最初に紹介したとされる論文は, Ullman, E. L., 'A theory of location for cities', American Journal of Sociology, 46, 1941, pp. 853-864. である。

63) Ullman, E. L., 'An autobiographical statement', in Boyce, R. R. ed., Geography as Spatial Interaction, Univ. Washington Press, 1980 , pp. 220-221.

64) Berry, B. J.L. and Harris, C. A., 'Walter Christaller: an appreciation', Geogr. Rev., 60, 1970, pp. 116-119.

65) Garrison, W. L., 'Playing with ideas', Ann. Assoc. Amer. Geogr., 69-3, 1979, pp. 118-120.

66) Dunn, E. S., Jr., The Location of Agricultural Production, Univ. of Florida Press, Gainsville, 1967, p. vii. 
駆使する社会学者 Duncan も，やはりワシント ン学派に近いところに位置している。そして, ワシントン大で経営学博士号を取得し, 商圈確 率モデルで有名な Huff [注44) (2194頁〕が, 同様 に商業構造を消費者行動から解明しょうとした ワシントン学派の Marble の近くに位置してい る。実際，Garrison が自らの回顧論文の中で 述べているように, ワシントン学派と Huff と は研究上の交流があったのである。なお, Huff と Marble の論文は, Berry and Pred の 分類では,「業務構造と消費者の外出行動との 関係 Relations of business structure and consumer shopping and travel habits」に分類さ れている。このことからも両者の親近性の高さ が裏付けられるのである。

それに対し, Philbrick, Platt, Mikesell, Harris といった伝統的地理学の立場に近いシ カゴ学派のクラスターは第 1 象限にみられる。 シカゴ学派のなかでも Philbrick は,「“空間的 機能組織” Areal Functional Organization」の 過去 30年間のフィールド・ワークとして師の. Plattの業績を多く引用しているため, 両者の 親近性が高く，互いに近くに位置している。こ のシカゴ学派の位置は, 同じく伝統的地理学を 代表するウィスコンシン大 (出身) の Trewartha, Barnes が, ワシントン学派と混在する形 で位置しているのと対照的である。それは， Trewartha, Barnes の研究が, 農村人口・集落 の分布を定量的に扱った点において，1950年代 以降展開する実証的な中心地研究の先駆であっ たからであろう。

ところで，第 2 図において，第 1 象限の離れ た位置に，モロッコの市場についてそのタイプ を研究している Fogg がひとりだけ布置されて いるのが目を引く。Foggは, Mikesell に3 回 以上引用されたために分析の対象となったので
あるが, 他の中心地研究者の誰とも引用・被引 用関係がないために，この様に離れて位置して いるのである。しかし, 各象限の周辺部に位置 している研究者でも, 複数の研究者と引用・被 引用関係にある場合には，Fogg ほど位置が原 点から離れてはいない。例えば，第 2 象限の $\mathrm{Y}$ 軸寄りに位置している Parkins は Godlund と Murphyに引用されており，また，第 3 象限の 外縁に位置している Nebraska 大人類学教授の Robertsは, ハイウェイ沿いの商業の成立の決 定因子が人口よりも交通量であることを検証し た研究で, Eiselen, Carol と引用・被引用関係 にある。

これ以外にも，次のようなクラスターがみら れる。すなわち，第 1 象限の中でも Y 軸に近い 部分には, Murphy, Hywel-Davies, Hartman, W. J. Berry, Scott といった CBD の研究者達 のクラスターがみられ，X軸に近い部分には, 最初に都市内部中心地の研究を手がけたとされ る Carol〔注54) 84頁〕を核とし，都市内部中心 地研究者の Vance, Proudfoot らのクラスター が第 4 象限にかけてみられる（第 4 図参照）。

一方, ショッピング・センター研究の基礎を 築いた Applebaum, マーケティングを扱って いる Eiselen, H. L. Green, Cohen, Epstein ら のクラスターが第 4 象限にみられる（第 4 図参 照)。彼らの研究は, Berry and Pred の分類で は「計画的ショッピング・センターPlanned shopping centers」や「小売商圈 - 都市勢力圈 の計測 : 商店立地研究 On measurering retail trade areas and urban dominance fields: store location research」関係の文献のところ にまとめられている。

このように，2次元の引用空間には全体とし て特徵をもったいくつかのクラスターがみいだ されるが，この座標を時計回りと反対方向に

67) Epstein, B. J., 'Evaluation of an established planned shopping center', Econ. Geogr., 37, 1961, pp. 12-21. 
$45^{\circ}$ 程回転させてみると（第 2 図参照），次のよ うな解釈もなしうる。回転後において，新しい $\mathrm{X}$ 軸の負の方向にはワシントン学派を中心とし た計量分析を用いる研究者が位置し，正の方向 にはシカゴ学派に代表されるような計量分析を 指向しない研究者が位置している。また，回転 後の新しいY軸の正の方向にはヨーロッパの研 究者が位置し, 負の方向には主にアメリカの研 究者が位置している。したがって，この引用空 間は, “計量分析対定性的記述” と “ヨーロッ パ地理学 (者) 対アメリカ地理学 (者)”の 2 つ の軸から基本的には構成されているといえよう。

\section{V むすび}

引用分析は，いみじくも Garfield が引用索 引の利用について指摘したように，「やみくも に，不適切に用いられる危険性」を有している かもしれない。計量書誌学的分析の解釈の適否 は，解釈を行なう者が，対象とする分野につい てどの程度の知見を有しているかに左右されて しまう可能性があるからである。しかし，少な くともある程度の予備知識は必要とするものの, その前提が満たされているならば，著者を分類 し計量的に評価することは，ある学問（のある 分野）の論文とそれに続く論文群の位置づけを 可能にし，それらのネットワークからその学問 (のある分野) の展開を理解するためのひとつの 有用な手法であるといえよう。

とりわけ，引用・被引用関係の MDSによる 計量書誌学的分析は, 研究の核となる研究者を 選び出し, 中心的なテーマのクラスターを抽出 し，それらを空間的に再現すること一すなわち， 被引用を J. Cole and S. Cole の第 3 の分類に 当たる「伝播の指標」として用いること一によ
って，研究者間のコミュニケーション・ネット ワークを再現することを可能とするものである。 このような観点のもとに，本稿では，まず， 図書館・情報学における引用分析, ならびに地 理学におけるこれまでの引用分析研究を概観し た後, MDSによる計量書誌学的分析の地理学 への適用事例として中心地研究をとりあげた。 なかでも，初期の頃の論文を選んだのは，既に 多くの研究がなされ，分野として確立している ため, それらの研究史上の位置づけと分析結果 との対応度をみることが可能だからである。

引用行列の MDS 分析の結果, 中心地研究の 研究者は, 国別, 学派別, 専門別にまとまりを もって 2 次元の引用空間上に位置しており，ヨ ーロッパとアメリカ, 計量的な研究と非計量的 な研究, のそれぞれに大別してグルーピングで きることがわかった。Gatrell は，0が多い原 データの引用分析に MDS を用いることに否定 的であった。本稿の原デー夕もこのような種類 のものであるが，分析結果をみる限りでは，か なり実際に即した引用・被引用関係の親近性空 間が復原されていると思われる。したがって, MDS を用いた引用分析は, 研究者間のコミュ ニケーション・ネットワークを解明する上での 有用な方法のひとつであると言えよう。

本稿で使用した原デー夕は, 英語圏を中心と した地理学関係の複数の雑誌論文の著者の引用 ・被引用関係を直接的にカウントしたものであ った。サンプルが少なかったことから，選ばれ た研究者が北米・英国を中心とした特定の領域 の研究者に限られてしまったが, かなり特徴が はっきりした中心地研究者のネットワークをみ ることができたように思われる。しかしより 正確に研究の展開を把握するためには,

68) Garfield, E., 'Citation indexes in sociological and historical research', American Documentation, 14-4, 1963, p. 289.

69）本稿で対象にした雑誌に採録されていなかったために，引用行列には入れなかったが，対象とした57人の研究者から計 5 回以上引用されている研究者は, 被引用数の多い順に以下の通りである。 W. J. Reilly, J.H. Kolb, C. J. Galpin. 
Christaller, Lösch の本国であるドイツにおけ る中心地研究，および，ヨーロッパの他の国々 のみならず，少なくとも Berry and Pred がと りあげた地理学関係の論文の大半をデー夕に加 えて考察したほうが望ましいであろうう。その際， 共著の場合のカウントの方法を変えたり, 共引 用や書誌結合の概念を用いた分析を行なって検 討してみることも心要と思われる。また，本稿 では検討しなかったが，地理学以外の他の学問 分野との関わりをみる意味で, “Central Place Studies”“゙取り上げられている社会学や経済学 など，他の学問分野の文献を含めた引用行列の
分析を行なうことによって, 中心地研究の研究 者のネットワークがより明確に本来の形に即し てみられるであろう。さらに時期を区切った分 析をすることにより，中心地研究の展開をみる ことも可能である。これらはいずれも今後の課 題である。

〔付記〕本稿を作成するに当たって，機会を与え てくださった東京都立大学地理学科の皆様に感謝 いたします。

なお，計算に当たっては，東京都立大学計算機 センターを利用した。

(東京都立大学)

\section{Communication Network of the Early Central Place Researchers \\ Recovered by Citation Analysis}

\section{Michiko HARAYAMA}

Citation analysis is a bibliometric method using reference citations found in scientific papers as the primary analytical tool. This paper attempts to clarify the communication network of one field in geography by means of citation analysis. Central place studies, originating from Christaller and Lösch, are selected for this purpose.

Citation is taken to represent four indicators as follows: 1) quality, 2) recognition, 3) diffusion and communication network, and 4) utilization. First, this paper reviews various measures used in citation analysis, such as bibliographic coupling, link connection, and co-citation, which have developed in the fields of Sociology of Science, and Library and Information Science. Multivariate data analyses, especially cluster analysis, factor analysis and multidimensional scaling (MDS), make it possible to deal with a large number of citation data such as the Scientific Citation Index (SCI) and the Social Sciences Citation Index (SSCI).

Second, citation analysis used in the field of geography is reviewed (see Table 1). According to the indicators mentioned above, the studies are divided into three categories: 1) quality of research, productivity and ranking, 2) professional recognition and reward, and 3) communication network and diffusion of ideas.

Third, to examine the communication network of geographers, the early central place studies are considered. In the present study, the citation frequency of 98 papers by 57 geographers which are taken from "Central Place Studies" (Berry and Pred, 1965) are counted directly, and an asymmetric matrix $(57 \times 57)$ is constructed. Citation frequencies are transformed into "distance"; hence the distance between geographers is analyzed by MDS, which assigns relative locations in two-dimensional space: the scaled configuration 
of highly cited and co-cited geographers would be a concrete representation of the communication network. It is expected that the 57 geographers comprise subgroups based on nationality, specialty and/or school.

In the present study, seven clusters are identified: 1) the Lund school, 2) the Chicago school, 3) the Washington school and researchers with theoretical and quantitative approaches, 4) English researchers, 5) CBD researchers, 6) researchers concentrating on the internal business structure of the city, and 7) marketing researchers (see Fig. 4).

As a result, reference space fundamentally consists of two axes: "quantitative analysis vs. qualitative description" and "European geographers vs. American geographers". When properly used, citation analysis can introduce a useful and effective measure of objectivity into the classification and evaluation of science and recover a communication network among researchers. 